Review

\title{
Finding the Perfect Membrane: Current Knowledge on Barrier Membranes in Regenerative Procedures: A Descriptive Review
}

\author{
Sorina-Mihaela Solomon ${ }^{1,+}{ }^{\dagger}$ Irina-Georgeta Sufaru ${ }^{1, *,+}$, Silvia Teslaru ${ }^{1,+}$, Cristina Mihaela Ghiciuc ${ }^{2,+}$ (b) \\ and Celina Silvia Stafie ${ }^{3, *,+}$ (i)
}

1 Department of Periodontology, Grigore T. Popa University of Medicine and Pharmacy Iasi, 16 Universitatii Street, 700115 Iasi, Romania; sorina.solomon@umfiasi.ro (S.-M.S.); silvia.teslaru@umfiasi.ro (S.T.)

2 Department of Morpho-Functional Sciences II-Pharmacology and Clinical Pharmacology, Faculty of Medicine, Grigore T. Popa University of Medicine and Pharmacy of Iași, 16 Universitatii Street, 700115 Iasi, Romania; cristina.ghiciuc@umfiasi.ro

3 Department of Preventive Medicine and Interdisciplinarity_Family Medicine Discipline, Faculty of Medicine, Grigore T. Popa University of Medicine and Pharmacy of Iasi, 16 Universitatii Street, 700115 Iasi, Romania

* Correspondence: ursarescu.irina@umfiasi.ro (I.-G.S.); celina.stafie@umfiasi.ro (C.S.S.)

+ These authors contributed equally to this work.

check for updates

Citation: Solomon, S.-M.

Sufaru, I.-G.; Teslaru, S.;

Ghiciuc, C.M.; Stafie, C.S. Finding the Perfect Membrane: Current

Knowledge on Barrier Membranes in

Regenerative Procedures:

A Descriptive Review. Appl. Sci. 2022, 12, 1042. https://doi.org/10.3390/ app12031042

Academic Editor: Vittorio Checchi

Received: 23 December 2021

Accepted: 17 January 2022

Published: 20 January 2022

Publisher's Note: MDPI stays neutral with regard to jurisdictional claims in published maps and institutional affiliations.

Copyright: (C) 2022 by the authors. Licensee MDPI, Basel, Switzerland. This article is an open access article distributed under the terms and conditions of the Creative Commons Attribution (CC BY) license (https:// creativecommons.org/licenses/by/ $4.0 /)$.

\begin{abstract}
Guided tissue regeneration (GTR) and guided bone regeneration (GBR) became common procedures in the corrective phase of periodontal treatment. In order to obtain good quality tissue neo-formation, most techniques require the use of a membrane that will act as a barrier, having as a main purpose the blocking of cell invasion from the gingival epithelium and connective tissue into the newly formed bone structure. Different techniques and materials have been developed, aiming to obtain the perfect barrier membrane. The membranes can be divided according to the biodegradability of the base material into absorbable membranes and non-absorbable membranes. The use of absorbable membranes is extremely widespread due to their advantages, but in clinical situations of significant tissue loss, the use of non-absorbable membranes is often still preferred. This descriptive review presents a synthesis of the types of barrier membranes available and their characteristics, as well as future trends in the development of barrier membranes along with some allergological aspects of membrane use.
\end{abstract}

Keywords: guided tissue regeneration; guided bone regeneration; barrier membranes; allergology

\section{Introduction}

Periodontitis is an infectious disease, often of multifactorial etiology, in which the perio-pathogenic bacterial biofilm plays an important role. The disease is characterized by an inflammatory reaction of the host to the bacterial aggression, reactions on which both local and systemic risk factors can be grafted. In the evolution of periodontitis, through the aggressive action of bacterial factors in the context of hyper-inflammatory status, there is a gradual destruction of the supporting periodontal tissues: periodontal ligaments, cementum and alveolar bone. To address this issue, periodontal therapy has evolved over time through regenerative therapy surgical methods that include guided tissue regeneration (GTR) and bone regeneration (GBR) techniques. Such guided techniques involve isolating the bone defect with the help of barrier membranes, allowing the regeneration of lost and damaged tissues [1]. The use of a barrier membrane, at the interface with the gingival/epithelial connective tissue and with periodontal ligaments and alveolar bone to promote the regeneration of periodontal tissues is called GTR, and the restoration of alveolar bone sites is called GBR.

The association of barrier membranes and biomaterials of infrabony periodontal lesions investigated in various clinical studies generated significantly better results in 
terms of attachment gain and reduction of probing depths than the open flap debridement alone [2-4].

In guided tissue regeneration, there is a number of four essential biological principles under the PASS acronym: (a) Primary closure of the surgical wound to allow uninterrupted healing; (b) Angiogenesis for adequate blood supply (supply of nutrients, as well as cell types that facilitate healing); (c) maintaining the Space for bone neo-formation, while blocking the proliferation of soft tissues and (d) wound Stability to allow blood clots to form [5].

The idea that the repopulation of cells on the root surface after periodontal surgery determines the nature of the attachment that will form is generally accepted. After the periodontal debridement, with or without open flap procedure, the root surface will be repopulated by the fastest cells, which were epithelial cells [6]. Barrier membranes placed over areas of tissue defect have as their main purpose the blocking of cell invasion from the gingival epithelium and connective tissue [7]. Barrier membranes require full in situ functionality for 4-6 weeks for periodontal tissue regeneration and 16-24 weeks for bone growth [8].

There are a number of mandatory requirements for a barrier membrane to be used successfully in guided regenerative therapies; these requirements include (a) good mechanical isolation, occlusion and blocking capabilities; (b) to be biologically active; (c) to be biocompatible; (d) to exhibit tolerance to exposure and (e) to be biodegradable [9]. Moreover, barrier membranes should have adequate porosity to prevent the excessive penetration of oral keratinocytes into the bone defect on one side but also to allow neovascularization and bone formation in the connective tissue part of the membrane [10]. It should also be easy to manipulate the membrane, to stabilize it at the site without damaging it [11].

To date, there is no commercially available membrane that meets all these parameters at optimum capacity, but recent developments in membrane production technology are trying, through various innovative forms, to meet as wide a range of characteristics as necessary to achieve predictable surgical results.

To meet some of these requirements, various techniques and materials have been developed to generate tissue neo-formation. They can be divided according to the biodegradability of the base material into absorbable membranes and non-absorbable membranes [12] (Figure 1). The use of absorbable membranes is extremely widespread due to their advantages, but in clinical situations of significant tissue loss, the use of non-absorbable membranes is often still preferred [13].

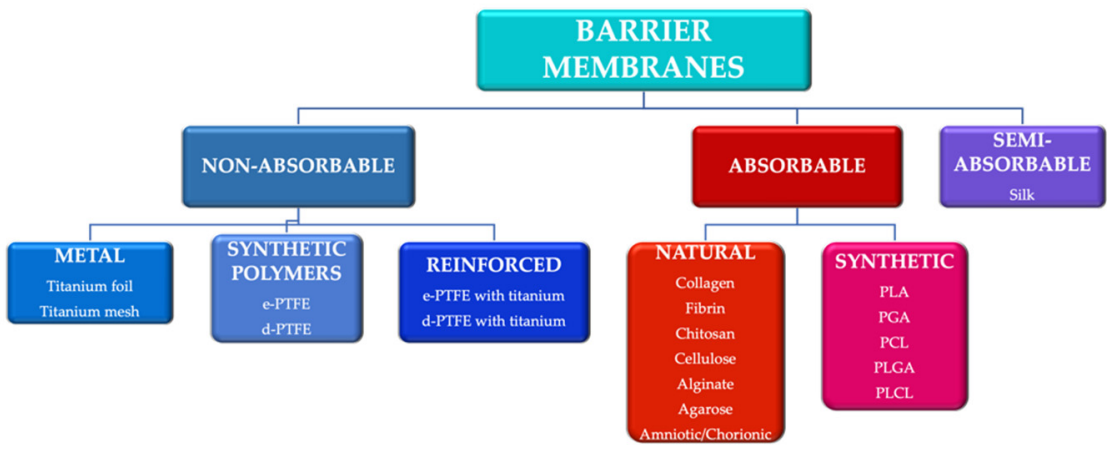

Figure 1. Main categories of barrier membranes used in guided tissue regeneration. e-PTFE: expanded polytetrafluoroethylene; d-PTFE: high density polytetrafluoroethylene; PLA: polylactic acid; PGA: polyglactic acid; PCL: polycaprolactone; PLGA: poly-lactic-co-glycolic acid PLCL: poly-lactic-cocaprolactone acid.

Another classification of barrier membranes includes the first generation of membranes (non-absorbable), second generation (absorbable) and third generation (membranes as a product of tissue engineering) [14]. 
We believe that a better understanding of the various types of membranes available and their properties is absolutely necessary in making clinical decisions. Thus, this review proposes a synthesis of the types of barrier membranes available and their characteristics; in addition, this paper presents future trends in the development of the field of barrier membranes, as well as some allergological aspects of membrane usage.

\section{Non-Absorbable Membranes}

Barrier membranes made of non-absorbable material are characterized by mechanical stability over time so that the by-products of degradation of the basic materials are not a cause for concern, and the period of fixation in place is easy to control [15]. Their setting to the anatomical substrate is usually done with the help of pins or mini-screws [16].

The major disadvantage of these membranes is the need for a second surgical time, removal from the site, after the completion of tissue neo-formation. This extra surgical time increases the risk of complications, such as infectious processes or healing disorders [12]. Moreover, non-absorbable membranes may present a higher risk of complications related to membrane exposure that include bacterial contamination or wound dehiscence $[17,18]$. Different types of non-absorbable membranes, with their advantages and disadvantages, are presented in Table 1.

Table 1. Types of non-absorbable membranes.

\begin{tabular}{|c|c|c|c|}
\hline \multicolumn{2}{|c|}{ Composition } & Commercial Variants & Observations \\
\hline \multicolumn{2}{|c|}{ Titanium } & $\begin{array}{l}\text { Osteo-Mesh TM- } 300^{\circledR} \\
\text { Frios BoneShields }\end{array}$ & $\begin{array}{c}\text { Very good mechanical properties } \\
\text { Bio-inert } \\
\text { High risk of oral exposure } \\
\text { Requires setting pins } \\
\text { Requires second surgical time }\end{array}$ \\
\hline \multicolumn{2}{|c|}{ Silicone } & & $\begin{array}{c}\text { Low cost } \\
\text { Bio-inert } \\
\text { Very low micro-porosity } \\
\text { Requires second surgical time }\end{array}$ \\
\hline \multirow{4}{*}{ Polytetrafluoroethylene (PTFE) } & Expanded (e-PTFE) & Gore-Tex $^{\circledR}$ & $\begin{array}{l}\text { Good mechanical properties } \\
\text { Good micro-porosity } \\
\text { Bio-inert } \\
\text { High risk of oral exposure, with } \\
\text { bacterial loading }\end{array}$ \\
\hline & $\begin{array}{l}\text { High density } \\
\text { (d-PTFE) }\end{array}$ & $\begin{array}{c}\text { High density Gore-Tex }{ }^{\circledR} \\
\text { Cytoplast TXT-200 } \\
\text { Cytoplast Regentex GBR-200 }\end{array}$ & $\begin{array}{l}\text { Good mechanical properties } \\
\text { Good micro-porosity } \\
\text { Smooth surface (low risk of } \\
\text { bacterial loading) } \\
\text { Can be left partially exposed in } \\
\text { the oral cavity } \\
\text { High risk of oral exposure }\end{array}$ \\
\hline & e-PTFE with titanium & Gore-Tex ${ }^{\circledR}$ Reinforced & $\begin{array}{c}\text { Very good mechanical properties } \\
\text { Bio-inert }\end{array}$ \\
\hline & d-PTFE with titanium & Cytoplast Regentex Ti-250 ${ }^{\circledR}$ & High risk of oral exposure \\
\hline
\end{tabular}

\subsection{Non-Absorbable Metal Membranes}

Titanium is the material of choice in making non-absorbable metal membranes. It is an inert, stable material with good mechanical strength; in addition, it has a high degree of biocompatibility $[19,20]$. These qualities of titanium make it usable in high-amplitude tissue defects, where it gives a constant shape over time [21]. An economic disadvantage is the high cost of these membranes compared to other common materials [12]. Titanium membranes may be available as all-metal membranes or metal mesh membranes.

In 2003, the Ultra-Ti ${ }^{\circledR}$ GTR titanium barrier membrane was introduced [22]. Ultra-Ti ${ }^{\circledR}$ membrane is a pure titanium membrane with a homogeneous structure, about 10 microns thick; due to its ultra-thin thickness, it is easy to handle and adapt to the receptor site [23]. Moreover, the surface roughness is reduced, which makes it less susceptible to bacterial contamination. In addition, it does not require setting with pins. Because it is radiolucent, 
it allows the monitoring of bone formation. As a disadvantage, being a non-porous membrane, it does not allow the perfect integration of tissues, which can lead to periodontal pocket formation [23].

In 1969, titanium mesh membranes were introduced to regenerate bone defects [24]. Titanium mesh has good mechanical properties in stabilizing bone regeneration materials. Its rigidity ensures the maintenance of the space and prevents the collapse of the defect; its elasticity prevents the compression of the mucosa, and its plasticity allows bending, contouring and adaptation to the bone defect [25]. Titanium mesh has been shown to maintain space with a higher degree of predictability, even in cases of extensive bone defects [26].

In general, titanium mesh membranes are characterized by macro-porosity; this quality is considered to play an important role in ensuring blood supply, allowing the diffusion of extracellular nutrients through the membrane [27]. Moreover, soft tissue attachment, favored by high porosity, facilitates the stabilization and restriction of epithelial cell migration [28]. Celletti et al. claimed in their study data that the use of a pore-free titanium membrane resulted in the exposure of all meshes in three weeks [29].

Of course, this type of membrane also has a number of disadvantages; due to its sharp edges, irritation of the soft tissue components can occur, which can lead to membrane exposure and even compromise therapeutic success [30]. However, titanium membranes can tolerate some degree of exposure. The exposure rate of titanium mesh membranes varies between $5.3 \%$ and $52 \%$ [31].

In a study of 44 patients who underwent titanium mesh-reinforced GTR, membrane exposure occurred in 23 cases, but graft failure occurred in only one patient [32]. In contrast, in another study, membrane exposure generated a bone resorption of $15-25 \%$ [33].

From the point of view of the predictability of the amount of newly formed bone, the studies generated discordant results, with growth values in vertical bone defects between $2.56 \mathrm{~mm}$ and $6 \mathrm{~mm}$ [32,34]. For increases in horizontal defects, the data indicate average values of $4 \mathrm{~mm}[32,35]$.

\subsection{Non-Absorbable Membranes of Synthetic Polymers}

From the category of synthetic polymers, polytetrafluoroethylene (PTFE) is an example of a material used in non-absorbable membranes. According to its structure, PTFE can be divided into two types: expanded PTFE (e-PTFE) and high density PTFE (d-PTFE) [24].

e-PTFE was developed in 1969 and became a standard material in the 1990s. Its structure is bi-layered, with pores between 5 and 20 microns in size. One side presents an open microstructure of $1 \mathrm{~mm}$ thickness, with $90 \%$ porosity, which delays epithelial growth, and on the other side there is a $0.15 \mathrm{~mm}$ thick membrane with $30 \%$ porosity, which generates space for new bone [36]. The main disadvantages of the e-PTFE membrane are the higher exposure rate and, of course, the need for a second surgical time to remove it from the site, a feature common to all non-absorbable membranes. Subsequently, in 1993, a high-density PTFE membrane (d-PTFE) was developed with pores smaller than 0.2 microns in diameter [36]. Research focused on d-PTFE has shown that surgical removal was easier for the d-PTFE membrane than for e-PTFE analogues, which could lead to fewer disruptions to the underlying tissue [12]. Due to its high density and micro-porosity, bacterial infiltration is much reduced [24]. Barber et al. reported that d-PTFE completely blocks the penetration of food and bacteria; thus, even if the membrane becomes exposed in the oral cavity, it maintains its functionality [37].

As both e-PTFE and d-PTFE had reduced mechanical stiffness, titanium mesh was introduced into their structure; this mesh or reinforcement is malleable for good adaptation to the receiving site [7]. Titanium-reinforced e-PTFE membranes have demonstrated higher space holding capacity and better stability than plain e-PTFE [38]. The Gore-Tex membrane (W.L. Gore \& Associates, Flagstaff, AZ, USA), which is made of e-PTFE, has been widely used in clinical treatment and has become a first choice-material for GTR and GBR. It is also widely used for general surgery, neurosurgery and cardiovascular surgery [39]. 


\subsection{Non-Absorbable Silk Membranes}

Silk is a material produced by the Bombyx mori silkworm (B. mori). It is a natural biopolymer, composed mainly of fibroin and sericin [40]. Silk fibroin was used as a biomaterial after the removal of sericin [41]; it is a compound characterized by high capacity for biocompatibility and tissue integration [42]. Silk fibroin membranes can generate a favorable adhesion of osteogenic cells, favoring bone neo-formation [43]. The major disadvantage of these membranes is the difficult handling as well as the low mechanical properties [44,45].

An alternative to simple silk membranes is given by the silk pad; it is produced from the cocoon of silkworms by a simple peeling method [46]. The silk pad has a number of benefits; it has a higher tensile strength in wet conditions than collagen and/or d-PTFE membranes [47]. Moreover, the obtaining procedure is a simple one, and at a low cost [48]. In addition, the silk pad has a high amount of sericin, which promotes bone neoformation [49,50]; Ha et al. demonstrated, in an animal model study, a similar level of bone regeneration for the silk pad compared to collagen or d-PTFE membranes [47].

\section{Absorbable Membranes}

Absorbable (or second-generation) membranes were developed with the primary goal of avoiding the need for a second surgical time of guided regeneration for the barrier membrane removal from the site. Depending on the material from which the absorbable membrane is made, they can be of natural or synthetic origin (Table 2). In addition, absorbable membranes are characterized by lower costs than non-absorbable membranes, as well as reduced risks of complications [51,52]. Mechanical instability of absorbable membranes is a major disadvantage. Creating and maintaining the space needed for bone formation may be compromised; thus, it is recommended to associate the membranes with bone replacement material to fill the bone defect [12]. Moreover, membrane degradation products can affect the process of tissue regeneration [53]; in addition, there is a risk of cross-infection in membranes of animal origin [54].

\subsection{Absorbable Membranes Made of Natural Polymers}

The most commonly used natural polymers for barrier membranes are type I collagen and type III collagen. BioMend Membrane (Zimmer Biomet Dental, Warsaw, IN, USA) was the first collagen-based membrane produced for guided tissue and bone regeneration application. Natural collagen is obtained by a decellularization process followed by steps of removal of any antigenic components [55].

Sources for collagen include human skin (Alloderm ${ }^{\circledR}$, LifeCell, Branchburg, NJ, USA), porcine skin (Bio-Gide ${ }^{\circledR}$, Geistlich, Shirley, NY, USA), porcine peritoneum (MemGuide ${ }^{\circledR}$, Ace, Boston, MA, USA) or Achilles' tendon (Cytoplast ${ }^{\circledR}$ RTM Collagen, Franklin Lakes, NJ, USA) $[14,56]$. After harvesting from the primary source, the product is subjected to decellularization, crosslinking and sterilization processes. The crosslinking treatment aims to increase the resistance of the membrane and can be achieved by different methods: UV irradiation or chemical processing. Glutaraldehyde, carbodiimide, hexamethylene diisocyanate, diphenyl-phosphoryl azide, formaldehyde or genipine can be used in chemical crosslinking [12,57]; other studies have also shown that crosslinking promoted prolonged biodegradation, reduced epithelial migration, decreased tissue integration and decreased vascularization $[14,58]$.

The main concern related to the use of chemical agents is given by the potential toxic and inflammatory reactions produced in the recipient organism [59]. To overcome these disadvantages, other cross-linking agents with low cytotoxicity have been developed, such as (a) diphenylphosphorylazide, with biocompatibility and good handling characteristics, without cytotoxic effects [60]; (b) 1-ethyl-3-(3-dimethylaminopropyl) carbodiimide, with high resistance and low cytotoxicity [61] and (c) epigallocatechin-3-gallate, with better mechanical properties and anti-inflammatory effects [62]. 
Table 2. Types of absorbable barrier membranes.

\begin{tabular}{|c|c|c|c|c|c|}
\hline Type & & & Commercial Variants & Absorption Time & Observations \\
\hline \multirow{14}{*}{ Natural } & \multirow{10}{*}{ Proteins } & \multirow{8}{*}{ Collagen } & BioGide $^{\circledR}$ & 24 weeks & \multirow{2}{*}{$\begin{array}{c}\text { From porcine dermis } \\
\text { Composition: type I and III collagen }\end{array}$} \\
\hline & & & Periogen $^{\circledR}$ & 4-8 weeks & \\
\hline & & & $\mathrm{RCM}$ & 26-38 weeks & \multirow{4}{*}{$\begin{array}{l}\text { From bovine tendon } \\
\text { Composition: } 100 \% \text { type I collagen }\end{array}$} \\
\hline & & & BioMend $^{\circledR}$ & 6-8 weeks & \\
\hline & & & BioMend-Extend ${ }^{\circledR}$ & 18 weeks & \\
\hline & & & OSSIX ${ }^{\circledR}$ & 6 months & \\
\hline & & & Paroguide $^{\circledR}$ & $4-8$ weeks & $\begin{array}{c}\text { From calfskin } \\
\text { Composition: } 96 \% \text { type I collagen, } \\
4 \% \text { chondroitin- } 4 \text {-sulfate }\end{array}$ \\
\hline & & & Alloderm ${ }^{\circledR}$ & 8-10 weeks & $\begin{array}{c}\text { From human cadaver } \\
\text { Composition: type I collagen }\end{array}$ \\
\hline & & & Autologous & 7-11 days & \\
\hline & & Fibrin & Etik-Patch $^{\circledR}$ & $4-6$ weeks & $\begin{array}{l}\text { Elastin and bovine fibrin with a } \\
\text { polyglactin mesh }\end{array}$ \\
\hline & \multirow{4}{*}{ Polysaccharides } & Chitosan & & 16-20 weeks & \\
\hline & & Cellulose & Nanoskin ${ }^{\circledR}$ & & \\
\hline & & Alginate & & & \\
\hline & & Agarose & & & \\
\hline \multirow{5}{*}{ Synthetic } & \multirow{2}{*}{\multicolumn{2}{|c|}{ PGA/TMC }} & Resolut Adapt $X^{\circledR}$ & \multirow{2}{*}{ 16-24 weeks } & \\
\hline & & & Resolut Adapt LT ${ }^{\circledR}$ & & \\
\hline & \multirow{2}{*}{ PLA } & \multirow{2}{*}{ Polylactic acid } & Guidor $^{\circledR}$ & \multirow{2}{*}{ 10-12 weeks } & \\
\hline & & & Epi-guide $^{\circledR}$ & & \\
\hline & \multicolumn{2}{|c|}{ PLA/PGA/TMC } & Resolut Adapt ${ }^{\circledR}$ & 8-10 weeks & \\
\hline & & PGA: polyglact & id; PLA: polylactic acic & MC: trimethyl chit & \\
\hline
\end{tabular}

Moreover, although crosslinked collagen membranes have prolonged degradation times, they also have significantly higher membrane exposure rates of up to $70.5 \%[63,64]$. As already mentioned, premature exposure of membranes is often associated with bacterial invasion, as demonstrated by Becker [65].

Collagen membranes can perform hemostatic functions, allowing and stimulating the attachment and proliferation of fibroblasts and osteoblasts due to the presence of arginineglycine-aspartic acid (Arg-Gly-Asp) and GFOGER sequences (glycine-phenylalaninehydroxyproline-glycine-glycine) integrin-specific [66]; data suggest that cellular activity begins $3-5$ days postoperatively [67]. At the same time, the membrane allows the signals from the cells associated with the membrane to be transferred to the cells in the bone defect, thus creating a favorable environment for bone neo-formation [68]. They can also be easily integrated with soft tissues and are permeable, so nutrient diffusion can be conducted easily $[69,70]$.

There are data on the performance of non-crosslinked type I collagen membranes with non-absorbable PTFE membrane that claim that non-crosslinked collagen membranes promote a high rate of vascularization at two months postoperatively [71]. Other studies have compared the rate of bone formation of collagen membranes with e-PTFE membrane, both of which show similar results [26,72-74]; stromal cells attached to the collagen membrane promoted the production of fibroblast growth factor (FGF-2) and bone morphogenetic protein (BMP-2), stimulating bone regeneration. The influence of the use of collagen membrane in the regeneration of calvarial defects on Wistar rats was investigated; defects that were covered with collagen membranes demonstrated better bone regeneration than defects without membrane [75].

The resorption time differs for each membrane, from 8 to 38 weeks [76,77]. Accelerated resorption of the barrier membrane can compromise the success of surgery. In a study 
that looked at the degradation of uncoated collagen membranes, it was found that some membranes begin the resorption process in the first $8 \mathrm{~h}$ post-surgery [78].

Natural materials for making absorbable membranes include alginate and chitosan. Alginate is a dimeric polysaccharide with a structure composed of $\beta$-D-mannuronate and $\alpha$-L-guluronate blocks. It is found in the walls of brown algae cells and in some bacterial capsules [79]. Alginate is biocompatible, non-toxic and does not cause inflammatory reactions, but has poor mechanical strength and adhesion. This material remains widely used in dentistry in impression techniques [80].

Chitosan is a copolymer of glucosamine and N-acetyl-D-glucosamine, produced from crustacean chitin [81]. Like alginate, it is a biocompatible and flexible material, the degree of resorption of which depends on its molecular weight [82]; membranes made of chitosan have demonstrated bacteriostatic properties [14] but, due to their fragility, are difficult to handle and to apply [83].

\subsection{Absorbable Membranes of Synthetic Polymers}

A stage in the development of membrane technologies was the artificial design of absorbable materials. These materials include biodegradable aliphatic polyesters: (a) polylactic acid (PLA); (b) polyglycolic acid (PGA) and (c) polycaprolactone (PCL) and their copolymers: poly-lactic-co-glycolic acid (PLGA) or poly-lactic-co-caprolactone acid (PLCL) [84,85]. PLA can be used alone or copolymerized with PGA. Polyester degradation is determined by hydrolysis and dependent on the hydrophobicity of the polymer [86]; PLA being more hydrophobic than PGA, degradation time is, thus, prolonged.

Aliphatic polyester membranes are bio-absorbable; the resorption of these membranes depends on the polyester types and ratio [87]. They also have good workability and maneuverability. Major disadvantages include lack of rigidity, stability but also concerns about the interactions of their degradation products with the recipient organism [88]; inflammatory reactions due to macrophages and leukocytes around the membrane were observed during absorption [89].

Improving mechanical properties using only biodegradable polyester can be difficult, which is why their main clinical indication is for small vertical bone defects, with the association of bone regeneration materials [12]. A combination of different porosity layers was proposed: the less porous side could act as a barrier, preventing epithelial cell infiltration, and the other side in contact with bone defect would allow tissue integration. Such techniques have been used in the Guidor Matrix Barrier (Sunstar Americas Inc., Schaumburg, IL, USA) and Resolut (W.L. Gore and Associates, Newark, DE, USA). Woven fibers technique (Vicryl Periodontal Mesh; Ethicon Inc., Cornelia, GA, USA), or polymer solution dissolved during the surgical procedure and molded in a cassette to form the Atrisorb membrane (Atrix Laboratories, Fort Collins, CO, USA) have also been adopted [55].

Poly-lactic-co-glycolic acid (PLGA) can be prepared in different copolymer forms depending on the ratio between PLA and PGA; its advantages include biocompatibility and biodegradability, and it is also easy to process [90]. Hoornaert et al. [91] developed a bi-layered PLGA membrane, composed of a dense, thin film that prevents the growth of epithelial cells and a thick, microfiber layer in order to stabilize the blood clot and promote cell colonization; the absorption rate was similar to the monolayer membrane of PLGA, but the rate of bone neo-formation was higher compared to the PLGA membrane [92]. Similar results were obtained by Abe et al. [93] with a bi-layered membrane from PLCL. The authors also observed that the two-layer PLCL membrane reduced bacterial adhesion and prevented bacterial invasion inside the membrane.

\section{Enhanced Barrier Membranes}

No polymer, natural or synthetic, seems to be sufficient alone. Therefore, the trends were either to combine materials or to enhance them with additives. New membranes have been developed, with additional functions such as the release of beneficial agents: antibiotics, growth factors and adhesion factors. 


\subsection{Membranes with Inorganic Compounds}

In order to enhance the osteoconductive and osteoinductive effects, research has focused on the introduction into the structure of the barrier membrane of synthetic calcium phosphates (hydroxyapatite or $\beta$-tricalcium phosphate), single or combined in biphasic calcium phosphates. Such products allow vascular penetration, cell infiltration and attachment, cartilage formation and calcified tissue deposition [94,95]. Phipps et al. [95] showed that the membrane made of a mixture of particles of PCL, collagen and hydroxyapatite generated a rapid cell spread and a significant cell proliferation. Baek et al. [96] evaluated the effects of collagen membrane and a membrane of chitosan, fibroin and hydroxyapatite on calvarial defect in rats; the results were similar for both types of membranes, with the absence of inflammatory reactions [96].

Won et al. [97] compared the collagen membrane with a membrane made of PCL, PLGA and $\beta$-tricalcium phosphate; even if both membranes showed similar results in histological and histomorphometric analyses, the membrane made of PCL, PLGA and $\beta$-tricalcium phosphate generated a larger area of bone neo-formation [97].

Other studies have looked into potential effects of including zinc, magnesium, iron or strontium in the composition of the membrane. Zinc is an absolutely necessary mineral for skeletal growth and development [98], important in many physiological and metabolic processes [99]. The addition of $\mathrm{ZnO}$ in the structure of barrier membranes has generated improvements in the proliferation of osteoblasts, with an accelerated regenerative mechanism [100]; the use of zinc membranes has also demonstrated a faster healing process [101], as well as inhibiting the formation of bacterial biofilm [102,103]. In addition, Oh et al. [104] observed that PLA-Zn-bioactive glass membranes showed tensile strength, elongation and flexibility similar to those of zinc-free membranes [104].

Similar to zinc, magnesium is an important factor in bone metabolism, with both proliferative effects for osteoblasts and anti-osteoclastic effects [105]. The strength of the $\mathrm{Mg}$ alloy is higher than that of absorbable polymers, such as PLA; therefore, magnesium alloy can improve the mechanical properties of membranes. However, the rate of the degradation of magnesium alloy is too fast [106]. An in vitro study found that hydrofluoric acid coating can delay the corrosion of magnesium alloys [107]. Xin et al. [108] designed a barrier membrane made of PLA reinforced with a Mg alloy core, with a better loading capacity compared to membranes without $\mathrm{Mg}$ reinforcement; when fluorine-coated magnesium alloy was used, it showed better resistance to corrosion. The proliferation of fibroblasts and osteoblasts has also been easily achieved [109].

Strontium is involved in bone mineral metabolism by inducing osteogenesis, stimulating markers of differentiation and proliferation, and reducing apoptosis levels [109]. Kitayama et al. [110] studied the effect of covering rabbit calvarial defects with a collagen membrane with strontium and hydroxyapatite; after 24 weeks, they observed increased levels of newly mineralized bone and less residual grafting material compared to an unmodified collagen membrane [110].

Thus, membranes enhanced with inorganic compounds could offer a favorable alternative in GTR and GBR, but additional data are needed to optimize the protocols for the use of these membranes.

\subsection{Membranes with Antimicrobial Factors}

The inclusion of several antimicrobial substances, such as antibiotics or silver ions, has been investigated in the structure of barrier membranes. Metronidazole benzoate can be added to the layer in contact with the epithelial tissue, preventing bacterial adhesion and proliferation [111]. Favorable results of metronidazole supplementation were also obtained by Shi et al. [112] and Wang et al. [113]. Other studies have investigated the use of azithromycin [114], tetracyclines [115,116] or silver ions [117].

Techniques for loading silk fibroin with 4-hexylresorcinol have been developed; 4-hexylresorcinol is a natural phenolic compound, with antimicrobial, antioxidant and antimutagenic abilities [118]. Moreover, 4-hexylresorcinol has been shown to inhibit the 
pathways of nuclear factor- $\mathrm{kB}$ (NF- $\mathrm{kB}$ ) [119], a molecule involved in osteoclast differentiation, with a resorptive role. Favorable results have been obtained in vivo and in other studies $[120,121]$. One of the obstacles to the practical applicability of these membranes is represented by their poor mechanical properties [45].

The disadvantages observed in the membranes with antimicrobial agents were the fact that most of them generally have a short release time of the drug; moreover, some periodontal tissue infections often occur after a relatively long period of time after surgery [112]. A number of studies have shown that the highest concentration of antibacterial substance is released in the first 3 days postoperatively, decreasing progressively in the following days and often becoming insufficient in situations of need [122-124]. Thus, the research focused on the development of techniques for making enriched membranes with slow and adequate release of microbial agent in order to prevent the so-called "waste" of the agent in unnecessary situations. Xue et al. [125] managed to extend the release time of the antimicrobial agent to 15 days, using fibers with encapsulated nanotubes that were loaded with metronidazole.

Trying to obtain the "release as needed" of metronidazole incorporated into the barrier membrane, Shi et al. [112] investigated the effects of esterified and grafted metronidazole on the surface of PCL nanofiber pads modified by ester bonds as a barrier membrane; ester bonds can be selectively hydrolyzed by cholesterol esterase. Cholesterol esterase is an enzyme secreted by macrophages accumulated at the site of infection, the concentration of which is positively related to the severity of the infection. Increased cholesterol esterase results in an increased release of metronidazole from the membrane, with antibacterial action [112].

One of the major problems with the use of membranes with antimicrobial agent is the risk of generating resistant bacterial species [126]; thus, there is an absolute need for clear guidelines and protocols for the use of such membranes.

\subsection{Membranes with Growth Factors}

Growth factors have been the subject of numerous studies, being included both in bone addition material and in the structure of barrier membranes. These factors include the group of bone morphogenetic proteins (BMP), stromal cell derived factor 1 alpha (SDF-1 $\alpha$ ), transforming growth factor beta (TGF- $\beta$ ), platelet-derived growth factor (PDGF), growth factor rich in platelets (PRGF) or fibroblast growth factor-2 (FGF-2) [55].

Bone morphogenetic proteins are among the most powerful osteoinductive proteins; they have modulatory effects on the differentiation and functionality of cells involved in bone formation [127]. Jones et al. [128] and Hsu et al. [129] investigated the treatment of ePTFE and titanium membranes, respectively, with BMP-2, both studies providing favorable data on new bone formation. One study reported beneficial results of BMP-9 incorporation into the collagen barrier membrane; BMP-9 stimulated alkaline phosphatase activity as well as osteoblastic gene expression [130].

A number of studies have shown that BMP-6 induces bone neo-formation, favoring bone augmentation procedures [8,131]. Gümüşderelioğlu et al. [127] developed a biodegradable chitosan membrane whose porous surface that comes in contact with the bone surface was enriched with hydroxyapatite and BMP-6; in order to improve the resistance of chitosan, the membrane was treated with glycerol solution. The authors concluded that this membrane demonstrated osteogenic activity and prevented the migration of epithelial cells [127]. In another study, Soran et al. [132] showed that the application of BMP-6 improved the osteoblastic differentiation of mesenchymal stem cells derived from bone marrow in vivo. A polymeric membrane loaded with BMP-6 on the hydroxyapatite coated membrane surface was patented (WO2016186594A1) [133], with the aim of providing memory and osteogenic activity, supporting bone regeneration, preventing epithelial cell migration and eliminating inflammation.

Incorporation of BMP-9 into the collagen membrane in vivo has also generated favorable results for bone neoformation in horizontal defects [134]. Shalumon et al. [135] 
demonstrated favorable results regarding the differentiation of osteogenic cells in GTR therapies with chitosan-fibroin-hydroxyapatite membrane in which BMP was incorporated.

PDGF-enriched PLA membranes have been associated with improved regenerative effects $[136,137]$. Other studies investigating PLA membranes with TGF- $\beta$ in alginate/nanofiber hybrid mesh have found effective regeneration in bone defects [138]. In another in vivo study, a six-fold increase in bone volume was observed when using a $\mathrm{PCL} /$ gelatin membrane enriched with SDF- $1 \alpha$ compared to the use of titanium membrane [139].

Major disadvantages of growth factors supplementation in the structure of barrier membranes include the high production cost, but also the fact that the doses are usually over-physiological, with potential adverse effects $[55,140]$.

\section{Trends in the Development of Barrier Membranes}

\subsection{Amniotic and Chorionic Membranes}

Amniotic and chorionic membranes are biological membranes, which means that they are bio-absorbable and compatible with tissues. The human placenta is essential in the development and survival of the fetus, ensuring physical and biological protection [141]. The amniotic membrane consists of a thick basal membrane and an avascular stromal matrix; this is the innermost layer of the placenta. Chorion forms the outer end of the sac and is made up of several types of collagen and bioactive components of cell adhesion [142]. Amniotic and chorionic membranes have been used in transplant surgery, proving healing, anti-inflammatory and antibacterial properties [143].

Membrane harvesting is usually done from healthy pregnant patients; caesarean section is preferred because vaginal birth placentas may be contaminated [141]. After harvesting, the collected placenta is placed in a sterile transport medium; to obtain the amniotic membrane, the amnion is separated from the underlying chorion along their natural plane of cleavage. Subsequently, the amniotic membrane is abundantly irrigated with a saline solution containing streptomycin, penicillin, neomycin and amphotericin prior to storage [143]. Methods of preserving the amniotic membrane include cryopreservation, lyophilization or air drying. Cryopreservation results in an improved retention of proteins and growth factors compared to lyophilization [144], but cryopreservation can affect the viability of cells in the amniotic membrane [145]. After lyophilization or air drying, it is necessary to sterilize the membrane with the help of gamma radiation [146] or with peracetic acid [147].

The amniotic membrane contains type IV, V and VI collagen as well as proteins (fibronectin, laminin, proteoglycans, glycosaminoglycans) [148]. The amniotic membrane contains laminin 5, a protein that stimulates the cell adhesion of gingival epithelial cells, collagen types I, II, IV, V and VI, platelet-derived growth factor, fibroblast growth factor and TGF- $\beta$ [149]. Perlecan found in the amniotic membrane plays an important role in binding growth factors and interacts with various cell adhesion molecules [150].

Histologically, the chorionic membrane consists of three layers: reticulate, basal membrane and trophoblastic. Collagen types I, III, IV, V, VI and VII, as well as proteoglycans are found in the crosslinked layer; the basal membrane contains type IV collagen, fibronectin and laminin [151]. Inhibitors of matrix metalloproteinases have been identified in the chorion, factors that can inhibit inflammatory status and stop collagen degradation [152].

Given these aspects, amniotic and chorion structures offer potential for use as barrier membranes in GTR and GBR. Such membranes have antibacterial and antifungal properties, minimize wound inflammation and provide a protein-rich matrix that allows cells to migrate more easily [153]. Moreover, the harvesting technique is relatively simple; by hydration with the blood, the membrane becomes malleable [142]. Major limitations include the risk of cross-contamination, as well as their fragility [151].

Amniotic and chorionic membranes have been shown to be effective in bone neoformation in periodontal defects, on canine [154] and human [155] subjects. Venkatesan et al. used an amniotic membrane in combination with an alloplastic biphasic bone substitute 
(60\% hydroxyapatite, $40 \%$ tricalcium phosphate) to treat infrabony defects; this membrane generated similar results to porcine-derived collagen membrane in terms of postoperative healing and the amount of newly formed bone [155]. Holtzclaw et al. [156] used an amnio-chorionic membrane to treat infrabony defects, observing significant improvements of clinical parameters (probing depth and loss of periodontal clinical attachment) at 12 months [156]. Another study compared the effects of lyophilized amniotic membrane and collagen membrane on newly formed bone density; the bone density of defects treated with amniotic membrane was higher than the sites where no barrier membrane was used and equivalent to the density obtained with collagen membrane $(p<0.05)$ at 3 weeks [157].

The amniotic membrane has also been used successfully in periodontal muco-gingival surgery; the association of the amniotic membrane with repositioned flaps has generated favorable results in covering the gingival recessions and in increasing the thickness of the attached gingiva $[158,159]$.

An amniotic membrane with different potential areas of use was patented (US6326019B1) [160], but its usage was directed mainly in skin and mucosal grafting. Actishield $^{\mathrm{TM}}$ (Wright Medical, Memphis, TN, USA) was also developed, but with main indication for orthopedic surgery. Up to date, there is no approved commercial amniotic/chorionic membrane for periodontal tissue regeneration. Nevertheless, in all types of membranes, Quality by Design principles and regulations have been introduced in order to obtain benefits of an integrated and risk-free approach to the industrialization process in membranes manufacturing [55].

\subsection{Barrier Membranes from PRF}

Platelet concentrates have been a research topic for more than 20 years; platelet-rich plasma, discovered in the late 1990s, was the result of centrifugation of blood harvested on the spot from the patient, offering good advantages in oral and maxillofacial surgery [161]. This procedure, on the other hand, had disadvantages related to the use of anticoagulants that could interfere with the healing process. Subsequently, a new product without anticoagulant was developed, platelet-rich fibrin (PRF). PRF has been shown to significantly increase the potential for tissue regeneration, favoring the slow and gradual release of growth factors trapped in its fibrin matrix [162].

PRP has been used primarily for soft tissue regeneration rather than osteogenesis and requires more blood than PRF. PRP is centrifuged at a higher rate, causing all heavy white blood cells and stem cells to sink to the base of the tube, not being collected in the sample [163]. Further research has found that a higher platelet concentration with the inclusion of white blood cells and stem cells in the sample would be even more therapeutic. The inclusion of white blood cells helped prevent postoperative infection, and the presence of stem cells generated an obvious capacity for regeneration. PRF is centrifuged at a slower rate, which causes a higher concentration of white blood cells, stem cells and platelets to remain in the middle plasma layer. Thus, PRF has a platelet concentration almost double that of blood. Platelets are involved in the release of growth and clotting factors. If the release of the growth factor occurs rapidly in the case of PRP, it is slow for PRF, with an average duration of 7-10 days postoperatively [164].

Lekovic et al. [165] investigated the association of PRF with bovine xenograft in filling periodontal infrabony defects in patients with bilateral defects, evaluating treatment with PRF alone or with PRF combined with bovine bone. Results after 6 months were more favorable when PRF was combined with bovine bone; they noticed a decrease in probing depth and gains in periodontal attachment and bone height. Lekovic et al. concluded that increased efficacy during bone defect regeneration treatment is achieved by the combination of PRF and xenograft, rather than by PRF alone [165]. Mathur et al. [166] compared the efficacy of PRF and autologous bone graft to increase attachment and reduce infrabony defects. Subjects showed infrabony defects that were treated with either an access flap associated with PRF or an access flap supplemented with an autologous bone graft; the third control group followed only the access flap procedure. Plaque index, the gingival 
index, the loss of attachment, the gingival recession and the depth of the periodontal pockets were analyzed on the day of surgery and 9 months later. The use of PRF had a more efficient result than the access flap alone, but the combination of the regenerating material allowed for obtaining an even more efficient treatment [166].

PRF has also proven effective in treating gingival recessions. Anilkumar et al. [167] compared PRF and connective tissue grafting with lateral repositioned flap to cover Miller class II recessions. Recession coverage was complete for $91 \%$ of patients treated with PRF, compared with $66 \%$ for those treated with a connective graft [167]. Jankovic et al. [168], in a treatment of Miller class I or II recessions, compared the results of the use of PRF membranes and connective tissue graft, combined with coronally repositioned flaps and connective tissue graft. The parameters studied were the size of the recession, attachment gain, the height of the keratinized gingiva, the pocket depth, the quality and speed of wound healing and the patient's discomfort; clinical parameters were evaluated at baseline and after 12 months. The results were similar between the use of a PRF membrane and a connective graft. The authors noted that although the amount of acquired keratinized tissue is higher with the connective graft, PRF provided better healing and less discomfort to the patient [168]. Thus, PRF may be an interesting, effective and relatively low-cost option, but further studies are needed on larger study groups in order to establish accurate protocols.

\subsection{D Printed Membranes}

Three-dimensional printing aims to generate an individualized 3D object, according to a design developed by software (computer aided design - CAD), by depositing the chosen material layer by layer. Three-dimensional technology already has applications in various fields, such as the production of anatomical models and surgical guides or regenerative medicine. There are multiple methods of 3D printing, including fusion deposition modeling (FDM), stereolithography (SLA) or selective laser sintering (SLS), but FDM remains the technique of choice for bioprinting [169]. The biomaterials used include hydrogels in combination with living cells and/or growth factors, natural and synthetic bioplastics, proteins, polymer biomolecules and ceramics [170].

Natural biomaterials used in 3D printing techniques include collagen, agarose, alginate, chitosan, silk, gelatin, cellulose, hyaluronic acid and fibrin [171], and synthetic biomaterials include PLA, PGA, PLGA and PCL [172,173]. Decellularized matrix components containing both conserved cellular elements and specific signaling factors of high importance in regenerative processes can also be used, because the latter can guide the cells of the resident tissue or provide the host cells with the necessary instructions for tissue regeneration [174].

Tayebi et al. tested a 3D-printed membrane of sodium elastin/gelatin/hyaluronate in vitro; the membrane has shown good mechanical properties as well as a stimulation of fibroblast proliferation [10]. Bai et al. [175] developed an individualized membrane with 3D-printed titanium mesh; various types of titanium mesh designed with different diameters, and thicknesses were tested based on their mechanical strength by a three-point bending test and FEA. According to the authors, the mechanical properties of the titanium mesh increased when the thickness decreased $(0.5 \mathrm{~mm}$ to $0.3 \mathrm{~mm})$; by increasing mesh diameter ( $3 \mathrm{~mm}$ to $5 \mathrm{~mm}$ ), the mechanical properties of the mesh decreased [175].

A time dimension was added to 3D technology, with the appearance of being $4 \mathrm{D}$; $3 \mathrm{D}$ printed construction thus changes, resulting in a transition in shape, structure and function [176]. This technology is based on intelligent biomaterials that have the ability to undergo changes as a result of exposure to various stimuli (temperature, $\mathrm{pH}$, humidity, electric or magnetic fields, light, sound or a combination thereof) [177]. Thus, $4 \mathrm{D}$ bioprinting offers new directions for the development of tissue reconstruction techniques.

\section{Allergological Considerations}

The most common allergic reactions to various implants, reported in the literature, were with nickel, cobalt and even titanium, although the latter has a high biocompatibil- 
ity [178]. The titanium test was patch-type and was conducted later and not before the implant. Authors who tried a lymphoblastic transformation test (LLT) are cited, but did not have success. However, these reactions are very rare [108].

The implantation of biomembranes can give two types of reactions: type I reactions (non IgE dependent) and IV (delayed type). A type I immune-allergic reaction is manifested by immediate angioedema and type IV by late reactions, which occur after a few days, even weeks, from the implant [179].

Regarding biological biomembranes (platelet concentrate, amniotic and chorionic concentrate) the high risk is rejection, as well as type IV reactions, such as contact dermatitis or mucositis, due to the additives with which they are impregnated, and which have been previously described [180].

Prophylactic testing would not be indicated, as it has no real clinical predictive benefit. Especially in the case of titanium, the time of penetration into the tissues is long. If the patient develops an immediate allergic reaction, which occurs in a few minutes, it would require a prior sensitization of the patient so that he already has cellular memory, with a specific IgE dosage, such as the situation of another implant, and not necessarily in the dental field or for the patient to work in an industry that uses titanium or other metals invoked in biomembranes. Type IV reactions would occur within weeks or even 2 months after membrane insertion.

The only test that would be eloquent is the patch test (with reading at $30 \mathrm{~min}, 1 \mathrm{~h}, 24 \mathrm{~h}$, $72 \mathrm{~h}$ and 7 days), but only if after the placement of these membranes the suspicion of an allergic reaction arises. Additionally, if the reaction is not severe, such as anaphylactic shock, difficult to control generalized urticaria, or a Stevens Johnson-type reaction, it would be worthwhile to treat the reaction and keep the membrane in place, even if the test is positive.

What is the profile of a risk patient? This is best illustrated by the patient who has had an implant, such as knee, hip, etc., the patient who works in industries that handle these materials and may associate contact dermatitis and, practically, a patient who could have been professionally sensitized prior to a dental implant.

Would immunosuppressive treatment be justified or not, in the case of these delayed type allergic reaction implants? This might depend on the severity of the periodontal disease, the severity of the rejection reaction and the patient's choice (since these implants are not cheap and the immunosuppressive therapy might not be subsidized by the state in this situation).

\section{Conclusions}

There is a wide range of technologies and materials used in guided tissue regeneration, some of which are still in the in vitro or in vivo testing phase. The use of the barrier membrane associated with bone grafting materials has shown better results than its single use. Further studies are needed to develop treatment algorithms and protocols to obtain predictable, case-specific regenerative results. In order to respond to our aim, it is more than clear that the perfect barrier membrane is not quite here, but the choice of the most appropriate membrane relies on the particular case, as well as on the medical experience of the operator.

Author Contributions: Conceptualization, S.-M.S. and C.S.S.; methodology, S.-M.S., C.S.S. and S.T.; validation, S.-M.S., I.-G.S. and C.S.S.; formal analysis, I.-G.S., S.T. and C.M.G.; investigation, I.-G.S., S.T. and C.M.G.; resources, S.-M.S. and C.S.S.; data curation, I.-G.S., S.T., C.M.G.; writing-original draft preparation, I.-G.S., C.S.S. and C.M.G.; writing—review and editing, S.-M.S., C.M.G. and S.T.; visualization, S.-M.S.; supervision, S.-M.S. and C.S.S.; project administration, C.S.S. All authors have read and agreed to the published version of the manuscript.

Funding: This research received no external funding.

Institutional Review Board Statement: Not applicable.

Informed Consent Statement: Not applicable. 
Conflicts of Interest: The authors declare no conflict of interest.

\section{References}

1. Cheng, X.; Yang, F. More than just a barrier-challenges in the development of guided bone regeneration membranes. Matter 2019, 1, 550-644. [CrossRef]

2. Trombelli, L.; Heitz-Mayfield, L.; Needleman, I.; Moles, D.; Scabbia, A. A systematic review of graft materials and biological agents for periodontal intraosseous defects. J. Clin. Periodontol. 2002, 29 (Suppl. S3), 117-135. [CrossRef] [PubMed]

3. Murphy, K.G.; Gunsolley, J.C. Guided tissue regeneration for the treatment of periodontal intrabony and furcation defects. A systematic review. Ann. Periodontol. 2003, 8, 266-302. [CrossRef]

4. Needleman, I.G.; Worthington, H.V.; Giedrys-Leeper, E.; Tucker, R.J. Guided tissue regeneration for periodontal infra-bony defects. Cochrane Database Syst. Rev. 2006, 19, CD001724. [CrossRef]

5. Wang, H.L.; Boyapati, L. “PASS" principles for predictable bone regeneration. Implant. Dent. 2006, 15, 8-17. [CrossRef] [PubMed]

6. Melcher, A.H. On the repair potential of periodontal tissues. J. Periodontol. 1976, 47, 256-260. [CrossRef] [PubMed]

7. Liu, J.; Kerns, D.G. Mechanisms of guided bone regeneration: A review. Open Dent. J. 2014, 8, 56-65. [CrossRef]

8. Caballe-Serano, J.; Abdeslam-Mohammed, Y.; Munar-Frau, A.; Fujioka-Kobayashi, M.; Hernandez-Alfaro, F.; Miron, R. Adsorption and release kinetics of growth factors on barrier membranes for guided tissue/bone regeneration: A systematic review. Arch. Oral Biol. 2019, 100, 57-68. [CrossRef]

9. Sanz, M.; Dahlin, C.; Apatzidou, D.; Artzi, Z.; Bozic, D.; Calciolari, E.; De Bruyn, H.; Dommisch, H.; Donos, N.; Eickholz, P.; et al. Biomaterials and regenerative technologies used in bone regeneration in the craniomaxillofacial region: Consensus report of group 2 of the 15th European Workshop on Periodontology on Bone Regeneration. J. Clin. Periodontol. 2019, 46, 82-91. [CrossRef]

10. Tayebi, L.; Rasoulianboroujeni, M.; Moharamzadeh, K.; Almela, T.K.D.; Cui, Z.; Ye, H. 3D-printed membrane for guided tissue regeneration. Mater. Sci. Eng. C Mater. Biol. Appl. 2018, 84, 148-158. [CrossRef]

11. Dimitriou, R.; Mataliotakis, G.I.; Calori, G.M.; Giannoudis, P.V. The role of barrier membranes for guided bone regeneration and restoration of large bone defects: Current experimental and clinical evidence. BMC Med. 2012, 10, 81. [CrossRef] [PubMed]

12. Sasaki, J.I.; Abe, G.L.; Aonan, L.; Thongthai, P.; Tsuboi, R.; Kohno, T.; Imazato, S. Barrier membranes for tissue regeneration in dentistry. Biomater. Investig. Dent. 2021, 8, 54-63. [CrossRef] [PubMed]

13. Kaushal, S.; Kumar, A.; Khan, M.A.; Lal, N. Comparative study of nonabsorbable and absorbable barrier membranes in periodontal osseous defects by guided tissue regeneration. J. Oral Biol. Craniofac. Res. 2016, 6, 111-117. [CrossRef] [PubMed]

14. Lee, H.S.; Byun, S.H.; Cho, S.W.; Yang, B.E. Past, present, and future of regeneration therapy in oral and periodontal tissue: A review. Appl. Sci. 2019, 9, 1046. [CrossRef]

15. Soldatos, N.K.; Stylianou, P.; Koidou, V.P.; Angelov, N.; Yukna, R.; Romanos, G.E. Limitations and options using resorbable versus nonresorbable membranes for successful guided bone regeneration. Quintessence Int. 2017, 48, 131-147. [PubMed]

16. Wadhawan, A.; Gowda, T.M.; Mehta, D.S. Gore-tex ${ }^{\circledR}$ versus resolut adapt ${ }^{\circledR}$ GTR membranes with perioglas ${ }^{\circledR}$ in periodontal regeneration. Contemp. Clin. Dent. 2012, 3, 406-411. [CrossRef]

17. Machtei, E.E. The effect of membrane exposure on the outcome of regenerative procedures in humans: A meta-analysis. J. Periodontol. 2001, 72, 512-516. [CrossRef] [PubMed]

18. Verardi, S.; Simion, M. Management of the exposure of e-PTFE membranes in guided bone regeneration. Pract. Proced. Aesthetic Dent. 2007, 19, 111-117.

19. Ottria, L.; Lauritano, D.; Andreasi, B.M.; Palmieri, A.; Candotto, V.; Tagliabue, A.; Tettamanti, L. Mechanical, chemical and biological aspects of titanium and titanium alloys in implant dentistry. J. Biol. Regul. Homeost. Agents 2018, 32, 81-90.

20. Hanawa, T. Titanium-tissue interface reaction and its control with surface treatment. Front. Bioeng. Biotechnol. 2019, 17, 170. [CrossRef]

21. Hasegawa, H.; Masui, S.; Ishihata, H. New microperforated pure titanium membrane created by laser processing for guided regeneration of bone. Br. J. Oral Maxillofac. Surg. 2018, 56, 642-643. [CrossRef]

22. Wong, C. Guided Tissue Regeneration with Ultra-ti Titanium Membrane. 2003. Available online: http:/ / www.oralimplant.orghk/ newsletter/8no3.html (accessed on 20 December 2021).

23. Khanna, R.; Khanna, R.; Pardhe, N.D.; Srivastava, N.; Bajpai, M.; Gupta, S. Pure titanium (Ultra-Ti) in the treatment of periodontal osseous defects: A split-mouth comparative study. J. Clin. Diagn. Res. 2016, 10, ZC47-ZC51. [CrossRef]

24. Rakhmatia, Y.D.; Ayukawa, Y.; Furuhashi, A.; Koyano, K. Current barrier membranes: Titanium mesh and other membranes for guided bone regeneration in dental applications. J. Prosthodont. Res. 2013, 57, 3-14. [CrossRef]

25. Her, S.; Kang, T.; Fien, M.J. Titanium mesh as an alternative to a membrane for ridge augmentation. J. Oral Maxillofac. Surg. 2012, 70, 803-810. [CrossRef]

26. Zitzmann, N.U.; Naef, R.; Scharer, P. Resorbable versus nonresorbable membranes in combination with Bio-Oss for guided bone regeneration. Int. J. Oral Maxillofac. Implant. 1997, 12, 844-852.

27. Weng, D.; Hurzeler, M.B.; Quinones, C.R. Contribution of the periosteum to bone formation in guided bone regeneration. Clin. Oral Implant. Res. 2000, 11, 546-554. [CrossRef]

28. Shanaman, R.; Filstein, M.R.; Danesh-Meyer, M.J. Localized ridge augmentation using GBR and platelet-rich plasma: Case reports. Int. J. Periodont. Restor. Dent. 2001, 21, 345-355. 
29. Celletti, R.; Davarpanah, M.; Etienne, D.; Pecora, G.; Tecucianu, J.F.; Djukanovic, D.; Donath, K. Guided tissue regeneration around dental implants in immediate extraction sockets: Comparison of e-PTFE and a new titanium membrane. Int. J. Periodontics Restor. Dent. 1994, 14, 243-253.

30. Watzinger, F.; Luksch, J.; Millesi, W. Guided bone regeneration with titanium membranes: A clinical study. Br. J. Oral Maxillofac. Surg. 2000, 38, 312-315. [CrossRef] [PubMed]

31. Briguglio, F.; Falcomata, D.; Marconcini, S.; Fiorillo, L.; Briguglio, R.; Farronato, D. The use of titanium mesh in guided bone regeneration: A systematic review. Int. J. Dent. 2019, 2019, 9065423. [CrossRef] [PubMed]

32. Louis, P.J.; Gutta, R.; Said-Al-Naief, N.; Bartolucci, A.A. Reconstruction of the maxilla and mandible with particulate bone graft and titanium mesh for implant placement. J. Oral Maxillofac. Surg. 2008, 66, 235-245. [CrossRef]

33. Maiorana, C.; Santoro, F.; Rabagliati, M.; Salina, S. Evaluation of the use of iliac cancellous bone and anorganic bovine bone in the reconstruction of the atrophic maxilla with titanium mesh: A clinical and histologic investigation. Int. J. Oral Maxillofac. Implant. 2001, 16, 427-432.

34. Corinaldesi, G.; Pieri, F.; Sapigni, L.; Marchetti, C. Evaluation of survival and success rates of dental implants placed at the time of or after alveolar ridge augmentation with an autogenous mandibular bone graft and titanium mesh: A 3- to 8-year retrospective study. Int. J. Oral Maxillofac. Implant. 2009, 24, 1119-1128.

35. Miyamoto, I.; Funaki, K.; Yamauchi, K.; Kodama, T.; Takahashi, T. Alveolar ridge reconstruction with titanium mesh and autogenous particulate bone graft: Computed tomography-based evaluations of augmented bone quality and quantity. Clin. Implant. Dent. Relat. Res. 2011, 14, 304-311. [CrossRef] [PubMed]

36. Madhuri, S.V. Membranes for Periodontal Regeneration. Int. J. Pharm. Sci. Invent. 2016, 5, 19-24.

37. Barber, H.D.; Lignelli, J.; Smith, B.M.; Bartee, B.K. Using dense PTFE membrane without primary closure to achieve bone and tissue regeneration. J. Oral Maxillofac. Surg. 2007, 65, 748-752. [CrossRef]

38. Canullo, L.; Malagnino, V.A. Vertical ridge augmentation around implants by e-PTFE titanium- reinforced membrane and bovine bone matrix: A 24- to 54-month study of 10 consecutive cases. Int. J. Oral Maxillofac. Implant. 2008, 23, 858-866.

39. Lee, J.Y.; Kim, Y.K.; Yun, P.Y.; Oh, J.S.; Kim, S.G. Guided bone regeneration using two types of non-resorbable barrier membranes. J. Korean Assoc. Oral Maxillofac. Surg. 2010, 36, 275-279. [CrossRef]

40. Cao, Y.; Wang, B. Biodegradation of silk biomaterials. Int. J. Mol. Sci. 2009, 10, 1514-1524. [CrossRef]

41. Khan, M.M.R.; Tsukada, M.; Gotoh, Y.; Morikawa, H.; Freddi, G.; Shiozaki, H. Physical properties and dyeability of silk fibers degummed with citric acid. Bioresour. Technol. 2010, 101, 8439-8445. [CrossRef]

42. Vepari, C.; Kaplan, D.L. Silk as a biomaterial. Prog. Polym. Sci. 2007, 32, 991-1007. [CrossRef]

43. Yoo, C.K.; Jeon, J.Y.; Kim, Y.J.; Kim, S.G.; Hwang, K.G. Cell attachment and proliferation of osteoblast-like mg63 cells on silk fibroin membrane for guided bone regeneration. Maxillofac. Plast. Reconstr. Surg. 2016, 38, 17. [CrossRef]

44. Song, J.Y.; Kim, S.G.; Lee, J.W.; Chae, W.S.; Kweon, H.; Jo, Y.Y.; Lee, K.G.; Lee, Y.C.; Choi, J.Y.; Kim, J.Y. Accelerated healing with the use of a silk fibroin membrane for the guided bone regeneration technique. Oral Surg. Oral Med. Oral Pathol. Oral Radiol. 2011, 112, e26-e33. [CrossRef] [PubMed]

45. Kwon, K.J.; Seok, H. Silk protein-based membrane for guided bone regeneration. Appl. Sci. 2018, 8, 1214. [CrossRef]

46. Jo, Y.Y.; Kweon, H.Y.; Kim, D.W.; Baek, K.; Kim, M.K.; Kim, S.G.; Chae, W.S.; Choi, J.Y.; Rotaru, H. Bone regeneration is associated with the concentration of tumour necrosis factor-alpha induced by sericin released from a silk mat. Sci. Rep. 2017, 7, 15589. [CrossRef] [PubMed]

47. Ha, Y.Y.; Park, Y.W.; Kweon, H.; Jo, Y.Y.; Kim, S.G. Comparison of the physical properties and in vivo bioactivities of silkwormcocoon-derived silk membrane, collagen membrane, and polytetrafluoroethylene membrane for guided bone regeneration. Macromol. Res. 2014, 22, 1018-1023. [CrossRef]

48. Kweon, H.Y.; Jo, Y.Y.; Seok, H.; Kim, S.G.; Chae, W.S.; Sapru, S.; Kundu, S.; Kim, D.W.; Park, N.R.; Xiangguo, C.; et al. In vivo bone regeneration ability of different layers of natural silk cocoon processed using an eco-friendly method. Macromol. Res. 2017, 25, 806-816. [CrossRef]

49. Nayak, S.; Dey, T.; Naskar, D.; Kundu, S.C. The promotion of osseointegration of titanium surfaces by coating with silk protein sericin. Biomaterials 2013, 34, 2855-2864. [CrossRef] [PubMed]

50. Jo, Y.Y.; Oh, J.H. New resorbable membrane materials for guided bone regeneration. Appl. Sci. 2018, 8, 2157. [CrossRef]

51. Bottino, M.C.; Pankajakshan, D.; Nor, J.E. Advanced scaffolds for dental pulp and periodontal regeneration. Dent. Clin. N. Am. 2017, 61, 689-711. [CrossRef]

52. Eliaz, N. Corrosion of metallic biomaterials: A review. Materials 2019, 12, 407. [CrossRef] [PubMed]

53. Hoogeveen, E.J.; Gielkens, P.F.; Schortinghuis, J.; Ruben, J.L.; Huysmans, M.C.D.J.M.; Stegenga, B. Vivosorb as a barrier membrane in rat mandibular defects. An evaluation with transversal microradiography. Int. J. Oral Maxillofac. Surg. 2009, 38, 870-875. [CrossRef] [PubMed]

54. Wang, J.; Wang, L.; Zhou, Z.; Lai, H.; Xu, P.; Liao, L.; Wei, J. Biodegradable polymer membranes applied in guided bone/tissue regeneration: A review. Polymers 2016, 8, 115. [CrossRef] [PubMed]

55. Aprile, P.; Letourneur, D.; Simon-Yarza, T. Membranes for guided bone regeneration: A road from bench to bedside. Adv. Healthc. Mater. 2020, 9, 2000707. [CrossRef] [PubMed] 
56. Felipe, M.E.M.; Andrade, P.F.; Grisi, M.F.; Souza, S.L.; Taba, M., Jr.; Palioto, D.B.; Novaes, A.B., Jr. Comparison of two surgical procedures for use of the acellular dermal matrix graft in the treatment of gingival recession: A randomized controlled clinical study. J. Periodontol. 2007, 78, 1209-1217. [CrossRef]

57. Sbricoli, L.; Guazzo, R.; Annunziata, M.; Gobbato, L.; Bressan, E.; Nastri, L. Selection of collagen membranes for bone regeneration: A literature review. Materials 2020, 13, 786. [CrossRef] [PubMed]

58. Schwarz, F.; Rothamel, D.; Herten, M.; Sager, M.; Becker, J. Angiogenesis pattern of native and cross-linked collagen membranes: An immunohistochemical study in the rat. Clin. Oral Implant. Res. 2006, 17, 403-409. [CrossRef] [PubMed]

59. Ferreira, A.M.; Gentile, P.; Chiono, V.; Ciardelli, G. Collagen for bone tissue regeneration. Acta Biomater. 2012, 8, 3191-3200. [CrossRef]

60. Zahedi, C.S.; Miremadi, S.A.; Brunel, G.; Rompen, E.; Bernard, J.P.; Benque, E. Guided tissue regeneration in human Class II furcation defects using a diphenylphosphorylazide-cross-linked collagen membrane: A consecutive case series. J. Periodontol. 2003, 74, 1071-1079. [CrossRef]

61. Park, J.Y.; Jung, I.H.; Kim, Y.K.; Lim, H.C.; Lee, J.S.; Jung, U.W.; Choi, S.H. Guided bone regeneration using 1-ethyl-3-(3dimethylaminopropyl) carbodiimide (EDC)-cross-linked type-I collagen membrane with biphasic calcium phosphate at rabbit calvarial defects. Biomater. Res. 2015, 19, 15. [CrossRef]

62. Chu, C.; Deng, J.; Hou, Y.; Xiang, L.; Wu, Y.; Qu, Y.; Man, Y. Application of PEG and EGCG modified collagen-base membrane to promote osteoblasts proliferation. Mater. Sci. Eng. C Mater. Biol. Appl. 2017, 76, 31-36. [CrossRef] [PubMed]

63. Friedmann, A.; Gissel, K.; Soudan, M.; Kleber, B.M.; Pitaru, S.; Dietrich, T. Randomized controlled trial on lateral augmentation using two collagen membranes: Morphometric results on mineralized tissue compound. J. Clin. Periodontol. 2011, 38, 677-685. [CrossRef]

64. Bouguezzi, A.; Debibi, A.; Chokri, A.; Sioud, S.; Hentati, H.; Selmi, J. Cross-linked versus Natural Collagen Membrane for Guided Bone Regeneration? A Literature Review. Am. J. Med. Biol. Res. 2020, 8, 12-16.

65. Becker, J.; Al-Nawas, B.; Klein, M.O.; Schliephake, H.; Terheyden, H.; Schwarz, F. Use of a new cross-linked collagen membrane for the treatment of dehiscence-type defects at titanium implants: A prospective, randomized-controlled double blinded clinical multicenterstudy. Clin. Oral Implant. Res. 2009, 20, 742-749. [CrossRef] [PubMed]

66. Sun, D.; Song, B.; Sun, D. Cytocompatibility of collagen membranes with bladder transitional cells of rabbit in vitro. Zhongguo Xiu Fu Chong Jian Wai Ke Za Zhi 2004, 18, 217-219. [PubMed]

67. Pokrywczynska, M.; Jundzill, A.; Rasmus, M.; Adamowicz, J.; Balcerczyk, D.; Buhl, M.; Warda, K.; Buchholl, L.; Gagat, M.; Grzanka, D.; et al. Understanding the role of mesenchymal stem cells in urinary bladder regeneration-a preclinical study on a porcine model. Stem Cell Res. Ther. 2018, 9, 328. [CrossRef] [PubMed]

68. Omar, O.; Elgali, I.; Dahlin, C.; Thomsen, P. Barrier membranes: More than the barrier effect? J. Clin. Periodontol. 2019, 46, 103-123. [CrossRef]

69. Kirpatovskii, V.I.; Efimenko, A.Y.; Sysoeva, V.Y.; Mudraya, I.S.; Kamalov, D.M.; Akopyan, Z.A.; Kamalov, A.A. Collagen-1 membrane for replacing the bladder wall. Bull. Exp. Biol. Med. 2016, 162, 102-106. [CrossRef]

70. Brum, I.S.; Elias, C.N.; de Carvalho, J.J.; Pires, J.L.S.; Pereira, M.J.S.; de Biasi, R.S. Properties of a bovine collagen type I membrane for guided bone regeneration applications. e-Polymers 2021, 21, 210-221. [CrossRef]

71. Ghanaati, S. Non-cross-linked porcine-based collagen I-III membranes do not require high vascularization rates for their integration within the implantation bed: A paradigm shift. Acta Biomater. 2012, 8, 3061-3072. [CrossRef]

72. Bunyaratavej, P.; Wang, H.L. Collagen membranes: A review. J. Periodontol. 2001, 72, 215-229. [CrossRef] [PubMed]

73. Turri, A.; Elgali, I.; Vazirisani, F.; Johansson, A.; Emanuelsson, L.; Dahlin, C.; Thomsen, P.; Omar, O. Guided bone regeneration is promoted by the molecular events in the membrane compartment. Biomaterials 2016, 84, 167-183. [CrossRef]

74. Gueldenpfennig, T.; Houshmand, A.; Najman, S.; Stojanovic, S.; Korzinskas, T.; Smeets, R.; Gosau, M.; Pissarek, J.; Emmert, S.; Jung, O.; et al. The condensation of collagen leads to an extended standing time and a decreased pro-inflammatory tissue response to a newly developed pericardiumbased barrier membrane for guided bone regeneration. In Vivo 2020, 34, 985-1000. [CrossRef] [PubMed]

75. Fadel, R.A.; Samarani, R.; Chakar, C. Guided bone regeneration in calvarial critical size bony defect using a double-layer resorbable collagen membrane covering a xenograft: A histological and histomorphometric study in rats. Oral Maxillofac. Surg. 2018, 22, 203-213. [CrossRef]

76. Raz, P.; Brosh, T.; Ronen, G.; Tal, H. Tensile properties of three selected collagen membranes. BioMed Res. Int. 2019, $2019,5163603$. [CrossRef] [PubMed]

77. Roca-Millan, E.; Jané-Salas, E.; Estrugo-Devesa, A.; López-López, J. Evaluation of bone gain and complication rates after guided bone regeneration with titanium foils: A systematic review. Materials 2020, 13, 5346. [CrossRef]

78. Toledano, M.; Asady, S.; Toledano-Osorio, M.; García-Godoy, F.; Serrera-Figallo, M.A.; Benítez-García, J.A.; Osorio, R. Differential biodegradation kinetics of collagen membranes for bone regeneration. Polymers 2020, 12, 1290. [CrossRef]

79. Draget, K.I.; Smidsrød, O.; Skjåk-Bræk, G. Alginates from Algae. In Biopolymers Online; Steinbüchel, A., Ed.; Wiley-VCH Verlag GmbH \& Co. KGaA: Weinheim, Germany, 2005.

80. Catoira, M.C.; Fusaro, L.; Di Francesco, D.; Ramella, M.; Boccafoschi, F. Overview of natural hydrogels for regenerative medicine applications. J. Mater. Sci. Mater. Med. 2019, 30, 115. [CrossRef] [PubMed] 
81. Tharanathan, R.N.; Kittur, F.S. Chitin-the undisputed biomolecule of great potential. Crit. Rev. Food Sci. Nutr. $2003,43,61-87$. [CrossRef]

82. Lauritano, D.; Limongelli, L.; Moreo, G.; Favia, G.; Carinci, F. Nanomaterials for periodontal tissue engineering: Chitosan-based scaffolds. A systematic review. Nanomaterials 2020, 10, 605. [CrossRef]

83. Shah, A.T.; Zahid, S.; Ikram, F.; Maqbool, M.; Chaudhry, A.A.; Rahim, M.I.; Schmidt, F.; Goerke, O.; Khan, A.S.; Rehman, I.U. Tri-layered functionally graded membrane for potential application in periodontal regeneration. Mater. Sci. Eng. C Mater. Biol. Appl. 2019, 103, 109812. [CrossRef] [PubMed]

84. Annunziata, M.; Nastri, L.; Cecoro, G.; Guida, L. The use of Poly-d,l-lactic acid (PDLLA) devices for bone augmentation techniques: A systematic review. Molecules 2017, 22, 2214. [CrossRef] [PubMed]

85. Yoshimoto, I.; Sasaki, J.I.; Tsuboi, R.; Yamaguchi, S.; Kitagawa, H.; Imazato, S. Development of layered PLGA membranes for periodontal tissue regeneration. Dent. Mater. 2018, 34, 538-550. [CrossRef]

86. Woodard, L.N.; Grunlan, M.A. Hydrolytic degradation and erosion of polyester biomaterials. ACS Macro Lett. 2018 , 7, 976-982. [CrossRef]

87. Zamboulis, A.; Nakiou, E.A.; Christodoulou, E.; Bikiaris, D.N.; Kontonasaki, E.; Liverani, L.; Boccaccini, A.R. Polyglycerol hyperbranched polyesters: Synthesis, properties and pharmaceutical and biomedical applications. Int. J. Mol. Sci. 2019, $20,6210$. [CrossRef]

88. Elgali, I.; Omar, O.; Dahlin, C.; Thomsen, P. Guided bone regeneration: Materials and biological mechanisms revisited. Eur. J. Oral Sci. 2017, 125, 315-337. [CrossRef]

89. Hutmacher, D.; Hurzeler, M.B.; Schliephake, H. A review of material properties of biodegradable and bioresorbable polymers and devices for GTR and GBR applications. Int. J. Oral Maxillofac. Implant. 1996, 11, 667-678.

90. Gentile, P.; Chiono, V.; Carmagnola, I.; Hatton, P.V. An overview of poly(lactic-co-glycolic) acid (PLGA)-based biomaterials for bone tissue engineering. Int. J. Mol. Sci. 2014, 15, 3640-3659. [CrossRef]

91. Hoornaert, A.; d'Arros, C.; Heymann, M.F.; Layrolle, P. Biocompatibility, resorption and biofunctionality of a new synthetic biodegradable membrane for guided bone regeneration. Biomed. Mater. 2016, 11, 045012. [CrossRef] [PubMed]

92. Abe, G.L.; Sasaki, J.I.; Katata, C.; Kohno, T.; Tsuboi, R.; Kitagawa, H.; Imazato, S. Fabrication of novel poly(lactic acid/caprolactone) bilayer membrane for GBR application. Dent. Mater. 2020, 36, 626-634. [CrossRef]

93. Yuan, H.; Fernandes, H.; Habibovic, P.; de Boer, J.; Barradas, A.M.; de Ruiter, A.; Walsh, W.R.; van Blitterswijk, C.A.; de Bruijn, J.D. Osteoinductive ceramics as a synthetic alternative to autologous bone grafting. Proc. Natl. Acad. Sci. USA 2010, 107, 13614-13619. [CrossRef]

94. Tang, Z.; Li, X.; Tan, Y.; Fan, H.; Zhang, X. The material and biological characteristics of osteoinductive calcium phosphate ceramics. Regen. Biomater. 2018, 5, 43-59. [CrossRef]

95. Phipps, M.C.; Clem, W.C.; Catledge, S.A.; Xu, Y.; Hennessy, K.M.; Thomas, V.; Jablonsky, M.J.; Chowdhury, S.; Stanishevsky, A.V.; Vohra, Y.K.; et al. Mesenchymal stem cell responses to bone-mimetic electrospun matrices composed of polycaprolactone, collagen I and nanoparticulate hydroxyapatite. PLOS ONE 2011, 8, e16813. [CrossRef] [PubMed]

96. Baek, Y.Y.; Kim, J.H.; Song, J.M.; Yoon, S.Y.; Kim, H.S.; Shin, S.H. Chitin-fibroin-hydroxyapatite membrane for guided bone regeneration: Micro-computed tomography evaluation in a rat model. Maxillofac. Plast. Reconstr. Surg. 2016, 38, 14. [CrossRef] [PubMed]

97. Won, J.Y.; Park, C.Y.; Bae, J.H.; Ahn, G.; Kim, C.; Lim, D.H.; Cho, D.W.; Yun, W.S.; Shim, J.H.; Huh, J.B. Evaluation of 3D printed PCL/PLGA/ $\beta$-TCP versus collagen membranes for guided bone regeneration in a beagle implant model. Biomed. Mater. 2016, 7, 055013. [CrossRef] [PubMed]

98. Raj Preeth, D.; Saravanan, S.; Shairam, M.; Selvakumar, N.; Selestin Raja, I.; Dhanasekaran, A.; Vimalraj, S.; Rajalakshmi, S. Bioactive zinc(II) complex incorporated PCL/gelatin electrospun nanofiber enhanced bone tissue regeneration. Eur. J. Pharm. Sci. 2021, 160, 105768. [CrossRef] [PubMed]

99. Fraga, C.G.; Oteiza, P.I.; Keen, C.L. Trace elements and human health. Mol. Asp. Med. 2005, 26, 233-234. [CrossRef] [PubMed]

100. Toledano-Osorio, M.; Manzano-Moreno, F.J.; Ruiz, C.; Toledano, M.; Osorio, R. Testing active membranes for bone regeneration: A review. J. Dent. 2021, 105, 103580. [CrossRef] [PubMed]

101. Toledano, M.; Gutierrez-Pérez, J.L.; Gutierrez-Corrales, A.; Serrera-Figallo, M.A.; Toledano-Osorio, M.; Rosales-Leal, J.I.; Aguilar, M.; Osorio, R.; Torres-Lagares, D. Novel non-resorbable polymeric-nanostructured scaffolds for guided bone regeneration. Clin. Oral Investig. 2020, 24, 2037-2049. [CrossRef]

102. Bueno, J.; Sánchez, M.C.; Toledano-Osorio, M.; Figuero, E.; Toledano, M.; Medina-Castillo, A.L.; Osorio, R.; Herrera, D.; Sanz, M. Antimicrobial effect of nanostructured membranes for guided tissue regeneration: An in vitro study. Dent. Mater. 2020, 36, 1566-1577. [CrossRef]

103. Osorio, R.; Carrasco-Carmona, Á.; Toledano, M.; Osorio, E.; Medina-Castillo, A.L.; Iskandar, L.; Marques, A.; Deb, S.; Toledano- Osorio, M. Ex Vivo Investigations on bioinspired electrospun membranes as potential biomaterials for bone regeneration. J. Dent. 2020, 98, 103359. [CrossRef] [PubMed]

104. Oh, S.A.; Won, J.E.; Kim, H.W. Composite membranes of poly(lactic acid) with zinc-added bioactive glass as a guiding matrix for osteogenic differentiation of bone marrow mesenchymal stem cells. J. Biomater. Appl. 2012, 27, 413-422. [CrossRef]

105. Pang, K.M.; Lee, J.W.; Lee, J.Y.; Lee, J.B.; Kim, S.M.; Kim, M.J.; Lee, J.H. Clinical outcomes of magnesium-incorporated oxidised implants: A randomised double-blind clinical trial. Clin. Oral Implant. Res. 2014, 25, 616-621. [CrossRef] 
106. Li, X.; Qi, C.; Han, L.; Chu, C.; Bai, J.; Guo, C.; Xue, F.; Shen, B.; Chu, P.K. Influence of dynamic compressive loading on the in vitro degradation behavior of pure PLA and Mg/PLA composite. Acta Biomater. 2017, 64, 269-278. [CrossRef] [PubMed]

107. Tian, P.; Liu, X. Surface modification of biodegradable magnesium and its alloys for biomedical applications. Regen. Biomater. 2015, 2135, 151. [CrossRef] [PubMed]

108. Xie, Y.; Hu, C.; Feng, Y.; Li, D.; Ai, T.; Huang, Y.; Ai, T.; Huang, Y.; Chen, X.; Huang, L.; et al. Osteoimmunomodulatory effects of biomaterial modification strategies on macrophage polarization and bone regeneration. Regen. Biomater. 2020, 7, 233-245. [CrossRef]

109. Ehret, C.; Aid-Launais, R.; Sagardoy, T.; Siadous, R.; Bareille, R.; Rey, S.; Pechev, S.; Etienne, L.; Kalisky, J.; de Mones, E.; et al. Strontium-doped hydroxyapatite polysaccharide materials effect on ectopic bone formation. PLoS ONE 2017, 14, e0184663. [CrossRef]

110. Kitayama, S.; Wong, L.O.; Ma, L.; Hao, J.; Kasugai, S.; Lang, N.P.; Mattheos, N. Regeneration of rabbit calvarial defects using biphasic calcium phosphate and a strontium hydroxyapatite-containing collagen membrane. Clin. Oral Implant. Res. 2016, 27, e206-e214. [CrossRef]

111. Sam, G.; Pillai, B.R.M. Evolution of barrier membranes in periodontal regeneration- “Are the third generation membranes really here?". J. Clin Diagn. Res. 2014, 8, ZE14. [CrossRef]

112. Shi, R.; Ye, J.; Li, W.; Zhang, J.; Li, J.; Wu, C.; Xue, J.; Zhang, L. Infection-responsive electrospun nanofiber mat for antibacterial guided tissue regeneration membrane. Mater. Sci. Eng. C 2019, 100, 523. [CrossRef]

113. Wang, Y.; Jiang, Y.; Zhang, Y.; Wen, S.; Wang, Y.; Zhang, H. Dual functional electrospun core-shell nanofibers for anti-infective guided bone regeneration membranes. Mater. Sci. Eng. 2019, 100, 134. [CrossRef]

114. Mathew, A.; Vaquette, C.; Hashimi, S.; Rathnayake, I.; Huygens, F.; Hutmacher, D.W.; Ivanovski, S. Antimicrobial and immunomodulatory surface-functionalized electrospun membranes for bone regeneration. Adv. Healthc. Mater. 2017, 6, 10. [CrossRef]

115. Kütan, E.; Duygu-Çapar, G.; Özçakir-Tomruk, C.; Dilek, O.C.; Özen, F.; Erdoğan, Ö.; Özdemir, I.; Korachi, M.; Gürel, A. Efficacy of doxycycline release collagen membrane on surgically created and contaminated defects in rat tibiae: A histopathological and microbiological study. Arch. Oral Biol. 2016, 63, 15-21. [CrossRef]

116. Lian, M.; Sun, B.; Qiao, Z.; Zhao, K.; Zhou, X.; Zhang, Q.; Zou, D.; He, C.; Zhang, X. Bi-layered electrospun nanofibrous membrane with osteogenic and antibacterial properties for guided bone regeneration. Colloids Surf. B Biointerfaces 2019, 176, $219-229$. [CrossRef] [PubMed]

117. Ye, J.; Yao, Q.; Mo, A.; Nie, J.; Liu, W.; Ye, C.; Chen, X. Effects of an antibacterial membrane on osteoblast-like cells in vitro. Int. J. Nanomed. 2011, 6, 1853-1861. [CrossRef]

118. Kang, Y.J.; Noh, J.E.; Lee, M.J.; Chae, W.S.; Lee, S.Y.; Kim, S.G. The effect of 4-hexylresorcinol on xenograft degradation in a rat calvarial defect model. Maxillofac. Plast. Reconstr. Surg. 2016, 38, 29. [CrossRef] [PubMed]

119. Kim, S.G.; JeonG, J.H.; Park, Y.W.; SonG, J.Y.; Kim, A.S.; CHoI, J.Y.; Chae, W.S. 4-hexylresorcinol inhibits transglutaminase-2 activity and has synergistic effects along with cisplatin in KB cells. Oncol. Rep. 2011, 25, 1597-1602. [CrossRef] [PubMed]

120. Kim, M.K.; Park, Y.T.; Kim, S.G.; Park, Y.W.; Lee, S.K.; Choi, W.S. The effect of a hydroxyapatite and 4-hexylresorcinol combination graft on bone regeneration in the rabbit calvarial defect model. Maxillofac. Plast. Reconstr. Surg. 2012, 34, 377-383.

121. Seok, H.; Lee, S.W.; Kim, S.G.; Seo, D.H.; Kim, H.S.; Kweon, H.Y.; Jo, Y.Y.; Kang, T.Y.; Lee, M.J.; Chae, W.S. The effect of silk membrane plus 3\% 4-hexylresorcinol on guided bone regeneration in a rabbit calvarial defect model. Int. J. Ind. Entomol. 2013, 27, 209-217. [CrossRef]

122. Xue, J.; He, M.; Liang, Y.; Crawford, A.; Coates, P.; Chen, D.; Shi, R.; Zhang, L. Fabrication and evaluation of electrospun PCL-gelatin micro-/nanofiber membranes for anti-infective GTR implants. J. Mater. Chem. B 2014, 2, 6867-6877. [CrossRef]

123. Xue, J.; Shi, R.; Niu, Y.; Gong, M.; Coates, P.; Crawford, A.; Chen, D.; Tian, W.; Zhang, L. Fabrication of drug-loaded anti-infective guided tissue regeneration membrane with adjustable biodegradation property. Colloids Surf. B Biointerfaces 2015, 135, 846-854. [CrossRef] [PubMed]

124. Shi, R.; Xue, J.; Wang, H.; Wang, R.; Gong, M.; Chen, D.; Zhang, L.; Tian, W. Fabrication and evaluation of a homogeneous electrospun PCL-gelatin hybrid membrane as an anti-adhesion barrier for craniectomy. J. Mater. Chem. B 2015, 3, 4063-4073. [CrossRef] [PubMed]

125. Xue, J.; Niu, Y.; Gong, M.; Shi, R.; Chen, D.; Zhang, L.; Lvov, Y. Electrospun microfiber membranes embedded with drug-loaded clay nanotubes for sustained antimicrobial protection. ACS Nano 2015, 9, 1600-1612. [CrossRef] [PubMed]

126. Campoccia, D.; Montanaro, L.; Speziale, P.; Arciola, C.R. Antibiotic-loaded biomaterials and the risks for the spread of antibiotic resistance following their prophylactic and therapeutic clinical use. Biomaterials 2010, 31, 6363-6377. [CrossRef] [PubMed]

127. Gümüşderelioğlu, M.; Sunal, E.; Tolga Demirtaş, T.; Kiremitçi, A.S. Chitosan-based double-faced barrier membrane coated with functional nanostructures and loaded with BMP-6. J. Mater. Sci. Mater. Med. 2020, 31, 4. [CrossRef] [PubMed]

128. Jones, A.A.; Buser, D.; Schenk, R.; Wozney, J.; Cochran, D.L. The effect of rhBMP-2 around endosseous implants with and without membranes in the canine model. J. Periodontol. 2006, 77, 1184-1193. [CrossRef]

129. Hsu, Y.T.; Al-Hezaimi, K.; Galindo-Moreno, P.; O’Valle, F.; Al-Rasheed, A.; Wang, H.L. Effects of recombinant human bone morphogenetic protein-2 on vertical bone augmentation in a canine model. J. Periodontol. 2017, 88, 896-905. [CrossRef] 
130. Fujioka-Kobayashi, M.; Sawada, K.; Kobayashi, E.; Schaller, B.; Zhang, Y.; Miron, R.J. Recombinant human bone morphogenetic protein 9 (rhBMP9) induced osteoblastic behavior on a collagen membrane compared with rhBMP2. J. Periodontol. 2016, 87, e101-e107. [CrossRef]

131. Akman, A.C.; Tığlı, R.S.; Gümüşderelioğlu, M.; Nohutcu, R.M. Bone morphogenetic protein-6-loaded chitosan scaffolds enhance the osteoblastic characteristics of MC3T3-E1 cells. Artif. Organs 2010, 34, 65-74. [CrossRef]

132. Soran, Z.; Tığlı Aydın, R.S.; Gümüşderelioğlu, M. Chitosan scaffolds with BMP-6 loaded alginate microspheres for periodontal tissue engineering. J. Microencapsul. 2012, 29, 770-780. [CrossRef]

133. Lee, D.Y.; Lee, S.B.; Park, K.J.; Park, J.J. A Barrier Membrane Used in Periodontitis Treatment and a Production Method Thereof. WO2016186594A1, 24 November 2016.

134. Fujioka-Kobayashi, M.; Kobayashi, E.; Schaller, B.; Mottini, M.; Miron, R.J.; Saulacic, N. Effect of recombinant human bone morphogenic protein 9 (rhBMP9) loaded onto bone grafts versus barrier membranes on new bone formation in a rabbit calvarial defect model. J. Biomed. Mater. Res. A 2017, 105, 2655-2661. [CrossRef] [PubMed]

135. Shalumon, K.; Lai, G.J.; Chen, C.H.; Chen, J.P. Modulation of bone-specific tissue regeneration by incorporating bone morphogenetic protein and controlling the shell thickness of silk fibroin/chitosan/nanohydroxyapatite core-shell nanofibrous membranes. ACS Appl. Mater. Interfaces 2015, 7, 21170-21181. [CrossRef] [PubMed]

136. Park, Y.J.; Ku, Y.; Chung, C.P.; Lee, S.J. Controlled release of platelet-derived growth factor from porous poly(L-lactide) membranes for guided tissue regeneration. J. Control. Release 1998, 51, 201-211. [CrossRef]

137. Raja, S.; Byakod, G.; Pudakalkatti, P. Growth factors in periodontal regeneration. Int. J. Dent. Hyg. 2009, 7, 82-89. [CrossRef]

138. Chen, F.M.; Shelton, R.M.; Jin, Y.; Chapple, I.L.C. Localized delivery of growth factors for periodontal tissue regeneration: Role, strategies, and perspectives. Med. Res. Rev. 2009, 29, 472-513. [CrossRef]

139. Ji, W.; Yang, F.; Ma, J.; Bouma, M.J.; Boerman, O.C.; Chen, Z.; van den Beucken, J.J.; Jansen, J.A. Incorporation of stromal cell-derived factor- $1 \alpha$ in PCL/gelatin electrospun membranes for guided bone regeneration. Biomaterials 2013, 34, 735-745. [CrossRef]

140. Herford, A.S.; Miller, M.; Lauritano, F.; Cervino, G.; Signorino, F.; Maiorana, C. The use of virtual surgical planning and navigation in the treatment of orbital trauma. Chin. J. Traumatol. 2017, 20, 9-13. [CrossRef]

141. Fénelon, M.; Catros, S.; Meyer, C.; Fricain, J.-C.; Obert, L.; Auber, F.; Louvrier, A.; Gindraux, F. Applications of Human Amniotic Membrane for Tissue Engineering. Membranes 2021, 11, 387. [CrossRef]

142. Shankar, P.; Kumar, A.; Kumari, C.B.N.; Mahendra, J.; Ambalavanan, N. Amnion and chorion membrane in periodontal regeneration. Ann. Rom. Soc. Cell Biol. 2020, 24, 435-441.

143. Riau, A.K.; Beuerman, R.W.; Lim, L.S.; Mehta, J.S. Preservation, sterilization and de-epithelialization of human amniotic membrane for use in ocular surface reconstruction. Biomaterials 2010, 31, 216-225. [CrossRef]

144. Rodríguez-Ares, M.T.; López-Valladares, M.J.; Touriño, R.; Vieites, B.; Gude, F.; Silva, M.T.; Couceiro, J. Effects of lyophilization on human amniotic membrane. Acta Ophthalmol. 2009, 87, 396-403. [CrossRef] [PubMed]

145. Laurent, R.; Nallet, A.; Obert, L.; Nicod, L.; Gindraux, F. Storage and qualification of viable intact human amniotic graft and technology transfer to a tissue bank. Cell Tissue Bank. 2014, 15, 267-275. [CrossRef]

146. Jirsova, K.; Jones, G.L.A. Amniotic membrane in ophthalmology: Properties, preparation, storage and indications for graftingA review. Cell Tissue Bank. 2017, 18, 193-204. [CrossRef] [PubMed]

147. Shortt, A.J.; Secker, G.A.; Lomas, R.J.; Wilshaw, S.-P.; Kearney, J.N.; Tuft, S.J.; Daniels, J.T. The effect of amniotic membrane preparation method on its ability to serve as a substrate for the ex-vivo expansion of limbal epithelial cells. Biomaterials 2009, 30, 1056-1065. [CrossRef]

148. Mamede, A.C.; Carvalho, M.J.; Abrantes, A.M.; Laranjo, M.; Maia, C.J.; Botelho, M.F. Amniotic membrane: From structure and functions to clinical applications. Cell Tissue Res. 2012, 349, 447-458. [CrossRef]

149. Takashima, S.; Yasuo, M.; Sanzen, N.; Sekiguchi, K.; Okabe, M.; Yoshida, T.; Toda, A.; Nikaido, T. Characterization of laminin isoforms in human amnion. Tissue Cell 2008, 40, 75-81. [CrossRef]

150. Niknejad, H.; Peirovi, H.; Jorjani, M.; Ahmadiani, A.; Ghanavi, J.; Seifalian, A.M. Properties of the amniotic membrane for potential use in tissue engineering. Eur. Cell Mater. 2008, 15, 88-99. [CrossRef]

151. Lei, J.; Priddy, L.B.; Lim, J.J.; Koob, T.J. Dehydrated human amnion/chorion membrane (dHACM) allografts as a therapy for orthopedic tissue repair. Tech. Orthop. 2017, 32, 149-157. [CrossRef]

152. Nishihara, S.; Someya, A.; Yonemoto, H.; Ota, A.; Itoh, S.; Nagaoka, I.; Takeda, S. Evaluation of the expression and enzyme activity of matrix metalloproteinase-7 in fetal membranes during premature rupture of membranes at term in humans. Reprod. Sci. 2008, 15, 156-165. [CrossRef]

153. Chen, E.; Tofe, A. A literature review of the safety and biocompatibility of amnion tissue. J. Implant. Adv. Clin. Dent. 2010, 2, 67-75.

154. Ben Ali, L.M.S.; Mostafa Elazab, S. Amniotic membrane as a biodegradable barrier in technique of guided tissue regeneration in advanced periodontal disease in dogs: Histopathological assessment. Tissue Reg. Stem. Cell 2020, 2020, 1-16.

155. Venkatesan, N.; Lavu, V.; Balaji, S.K. Clinical efficacy of amniotic membrane with biphasic calcium phosphate in guided tissue regeneration of intrabony defects- a randomized controlled clinical trial. Biomater. Res. 2015, 25, 15. [CrossRef]

156. Holtzclaw, D.J.; Toscano, N.J. Amnion-chorion allograft barrier used for guided tissue regeneration treatment of periodontal intrabony defects: A retrospective observational report. Clin. Adv. Periodontics 2013, 3, 131-137. [CrossRef] 
157. Ríos, L.K.; Espinoza, C.V.; Alarcón, M.; Huamaní, J.O. Bone density of defects treated with lyophilised amniotic membrane versus collagen membrane: A tomographic and histomorfogenic study in rabbit's femur. J. Oral Res. 2014, 3, 143-149. [CrossRef]

158. Sharma, A.; Yadav, K. Amniotic membrane-A Novel material for the root coverage: A case series. J. Indian Soc. Periodontol. 2015, 19, 444-448. [CrossRef]

159. Shetty, S.S.; Chatterjee, A.; Bose, S. Bilateral multiple recession coverage with platelet-rich fibrin in comparison with amniotic membrane. J. Indian Soc. Periodontol. 2014, 18, 102-106. [CrossRef] [PubMed]

160. Tseng, S.C.G. Grafts Made from Amniotic Membrane; Methods of Separating, Preserving and Using Such Grafts in Surgeries. U.S. Patent US6326019B1, 4 December 2001.

161. Miron, R.J.; Pikos, M.A. PRF as a barrier membrane in guided bone regeneration. Dent. Today 2017, 216, 36.

162. Miron, R.J.; Bosshardt, D.D. OsteoMacs: Key players around bone biomaterials. Biomaterials 2016, 82, 1-19. [CrossRef]

163. Giannini, S.; Cielo, A.; Bonanome, L.; Rastelli, C.; Derla, C.; Corpaci, F.; Falisi, G. Comparison between PRP, PRGF and PRF: Lights and shadows in three similar but different protocols. Eur. Rev. Med. Pharmacol. Sci. 2015, 19, 927-930.

164. Kobayashi, E.; Flückiger, L.; Fujioka-Kobayashi, M.; Sawada, K.; Sculean, A.; Schaller, B.; Miron, R.J. Comparative release of growth factors from PRP, PRF, and advanced-PRF. Clin. Oral Investig. 2016, 20, 2353-2360. [CrossRef]

165. Lekovic, V.; Milinkovic, I.; Aleksic, Z.; Jankovic, S.; Stankovic, P.; Kenney, E.B.; Camargo, P.M. Platelet-rich fibrin and bovine porous bone mineral vs. platelet-rich fibrin in the treatment of intrabony periodontal defects. J. Periodontal. Res. 2012, 47, 409-417. [CrossRef] [PubMed]

166. Mathur, A.; Bains, V.K.; Gupta, V.; Jhingran, R.; Singh, G.P. Evaluation of infrabony defects treated with platelet-rich fibrin or autogenous bone graft: A comparative analysis. Eur. J. Dent. 2015, 9, 100-108. [PubMed]

167. Anilkumar, K.; Geetha, A.; Umasudhakar, T.R.; Vijayalakshmi, R.; Pameela, E. Platelet-rich-fibrin: A novel root coverage approach. J. Indian Soc. Periodontol. 2009, 13, 50-54. [CrossRef]

168. Jankovic, S.; Aleksic, Z.; Klokkevold, P.; Lekovic, V.; Dimitrijevic, B.; Kenney, E.B.; Camargo, P. Use of platelet-rich fibrin membrane following treatment of gingival recession: A randomized clinical trial. Int. J. Periodontics Restor. Dent. 2012, 32, e41-e50.

169. Yeong, W.Y.; Chua, C.K.; Leong, K.F.; Chandrasekaran, M. Rapid prototyping in tissue engineering: Challenges and potential. Trends Biotechnol. 2004, 22, 643-652. [CrossRef] [PubMed]

170. Skardal, A.; Atala, A. Biomaterials for integration with 3-D bioprinting. Ann. Biomed. Eng. 2015, 43, 730-746. [CrossRef] [PubMed]

171. Sears, N.A.; Seshadri, D.R.; Dhavalikar, P.S.; Cosgriff-Hernandez, E. A review of three-dimensional printing in tissue engineering. Tissue Eng. B Rev. 2016, 22, 298-310. [CrossRef]

172. Tamay, D.G.; Dursun Usal, T.; Alagoz, A.S.; Yucel, D.; Hasirci, N.; Hasirci, V. 3D and 4D printing of polymers for tissue engineering applications. Front. Bioeng. Biotechnol. 2019, 7, 164. [CrossRef]

173. Mobaraki, M.G.; Yazdanpanah, M.A.; Luo, Y.; Mills, D.K. Bioinks and bioprinting: A focused review. Bioprinting 2020, 2020 , e00080. [CrossRef]

174. Hospodiuk, M.; Dey, M.; Sosnoski, D.; Ozbolat, I.T. The bioink: A comprehensive review on bioprintable materials. Biotechnol. Adv. 2017, 35, 217-239. [CrossRef]

175. Bai, L.; Ji, P.; Li, X.; Gao, H.; Li, L.; Wang, C. Mechanical characterization of 3D-printed individualized Ti-mesh (membrane) for alveolar bone defects. J. Healthc. Eng. 2019, 2019, 4231872. [CrossRef] [PubMed]

176. Vanderburgh, J.; Sterling, J.A.; Guelcher, S.A. 3D printing of tissue engineered constructs for in vitro modeling of disease progression and drug screening. Ann. Biomed. Eng. 2017, 45, 164-179. [CrossRef] [PubMed]

177. Groll, J.; Burdick, J.A.; Cho, D.W.; Derby, B.; Gelinsky, M.; Heilshorn, S.C.; Jüngst, T.; Malda, J.; Mironov, V.A.; Nakayama, K.; et al. A definition of bioinks and their distinction from biomaterial inks. Biofabrication 2018, 11, 013001. [CrossRef] [PubMed]

178. Pacheco, K.A. Allergy to surgical implants. Clin. Rev. Allergy Immunol. 2019, 56, 72-85. [CrossRef] [PubMed]

179. Sicilia, A.; Cuesta, S.; Coma, G.; Arregui, I.; Guisasola, C.; Ruiz, E.; Maestro, A. Titanium allergy in dental implant patients: A clinical study on 1500 consecutive patients. Clin. Oral Implant. Res. 2008, 19, 823-835. [CrossRef] [PubMed]

180. Demoly, P.; Michel, F.; Bousquet, J. Allergy, Principles and Practice, 5th ed.; Mosby-Year Book: St. Louis, MO, USA, 1998; pp. $430-439$. 